\title{
Saving the Sustainability of the European Union, Fighting Terrorism
}

\author{
El Chami D \\ Timac Agro Italia, Località Ca' Nova, Ripalta Arpina (CR), Italy \\ El Moujabber $M$ \\ International Centre for Advanced Mediterranean Agronomic Studies \\ (CIHEAM-IAM.B), Valenzano (BA), Italy
}

Doi:10.19044/esj.2018.v14n17p149 URL:http://dx.doi.org/10.19044/esj.2018.v14n17p149

\begin{abstract}
Albeit the absence of an agreement on the definition, terrorism as studied in this literature has a complex nature and diverse factors that are involved. Furthermore, dealing with terrorism has become the centrepiece of foreign policies of many countries worldwide. The European Union has a long history of fighting terrorism. Yet, the current terrorism threats have shaken the bases of the Union. According to the authors' assessment and evaluation, terrorism in Europe, in the aftermath of the Second World War, occurs due to the unsustainable foreign policies of the EU member states. To save the European Union and to fight terrorism, the authors suggest a framework based on four complementary headlines: $i$ ) Education, ii) Social justice and human rights, iii) Law enforcement, and $i v$ ) Sustainable common defence policy. A prerequisite to the success of this framework is a revision of the Europe-transatlantic relations to address the imbalance in the EU relations with USA.
\end{abstract}

Keywords: Sustainable Framework, Fighting Terrorism, European Union, Education, Social Justice, Human Rights, Law Enforcement, Defence Policy, Transatlantic Relations

\section{Introduction}

Defining terrorism has been a hard-controversial endeavour as far as no definition could gain wide agreement among those concerned in the subject (Callaway \& Harrelson-Stephens, 2006; Weinberg et al., 2004). Simon (1994) notes the existence of 212 different definitions across the world. Although most of the definitions acknowledged that terrorism is the use of violence for the achievement of specific ends e.g. political, religious or ideological (Matusitz, 2013), there is still a controversy on one common 
basis for determining the legitimacy of using violence (directed at whom, by whom, for what ends). This difference in the definition could vary from a state or group to another: The United Nations General Assembly Resolution 49/60 and the United Nations Security Council Resolution 1566; the European Union Framework Decision on Combating Terrorism (2002); the United Kingdom's Terrorism Act 2000; and the United States Federal Criminal Code (Title 18, Section 2331 of Chapter 113(B)). The difference could even be between different agencies and groups within a state e.g. the United States Patriot Act of 2001, the United States Army Manual, and the United States Federal Bureau of Investigation (FBI).

Even though violence is associated to the human nature and history (Giorgi, 2001), the origin of the word "terrorism" dates to a more recent history, namely to the French Revolution of 1789. In the so-called "Reign of Terror" (or simply "Terror"), the ruling Jacobins employed violence for a period of eleven months (September 5, 1793 - July 28, 1794) to intimidate the regime's enemies (Conte, 2010; Stephens, 2004). Modern terrorism rose in the twentieth century, and only then it began to be associated with nonstate groups (Miller 2012). This is attributed mainly to the rise of anticolonial sentiments and a direct reaction to imperial hegemony.

Albeit the complex nature of terrorism and the diversity of factors involved, dealing with it has become the centrepiece of foreign policies of many countries worldwide. The military and intelligence operations have been on the top of the counter-terrorism measures. Surely, every conceivable weapon should be employed in self-defence. However, until present, all the measures and policies failed to make the European countries terrorist-proof, threatening the core European ideals and consequently the future of the Union. Thus, to effectively tackle the challenges in fighting terrorism, there is a need for an assessment of the situation, and an urgent need to develop a long-term strategy to fight terrorism and to remove its reasons for growth using all possible weapons, including the moral and spiritual ones, before it splits the Union apart. To support what we are suggesting, we recast here the concern of Malik (2015) describing the fight against communism: what about the moral and spiritual weapon?

\section{- Terrorism in the European Union}

The European Union has a long history of fighting terrorism (Zimmermann, 2006). The origin of terrorism attacking the European countries falls within the religious type. Indeed, the series of coordinated suicidal attacks that occurred in Paris (France) on 13 November 2015, and the three coordinated nail bombings that paralysed Brussels, the Belgian capital, on 22 March 2016, were perpetrated by the Islamic State (IS); and the arrest of many suspects related to Islamic terrorism in different part of 
Europe is another example. This type of terrorism could be extremely dangerous due to the fanaticism motivated by religious ideologies driving its followers to sacrifice themselves for an eternal reward (Hoffman, 2006).

The religious type of terrorism could be classified according to OPSEC (1996) in the 'non-state-supported' group that is autonomous and which does not receive governmental support. In some cases, it is 'statedirected' when it receives sponsoring government support. Despite western denials, different classified government documents and diverse exintelligence top officers have overtly proclaimed that the creation, the support, and the use of Islamic terrorism and terrorist groups have been the work of western countries and their close allies for specific political ends (Chengu, 2014).

The origin of terrorism in Europe goes back to the large-scale immigration into the old continent, which started in the early 1950s, in the aftermath of the Second World War when many European colonials lost their world power, causing large population movements from the lost colonies toward their mother country (de la Rica et al., 2013). This phenomenon has been on a continuous increase (Figure 1), making Europe a major destination of world immigration. Along with the overall increase of immigrants in Europe, Muslim populations constituted most of immigration flow mainly from Africa, the Middle East, and Asia (Leiken, 2005). The number of Muslims in Europe has grown from 29.6 million in 1990 (4.1\% of the population) to 44.1 million in 2010 , representing around $6 \%$ of the total European population. The number of the European Muslim population is projected to grow at an average annual growth rate of $1.5 \%$, which is about twice the rate of the non-Muslim population over the next two decades (PRC, 2011).

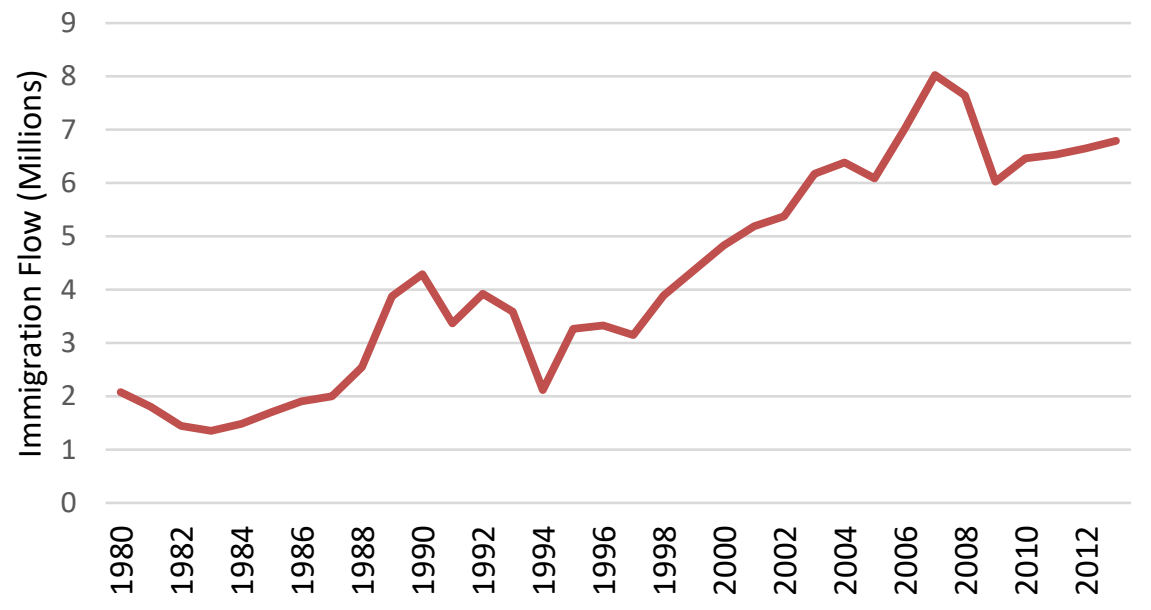

Figure 1. Trends of immigration to Europe (in millions) since 1980 (Modified after: UN, 2015a). 
At first, the ensuing immigrant inflows played an important role in the construction and for the economic expansion of the post-war Europe, and it turned many ethnically homogeneous countries into multi-ethnic societies (de la Rica et al., 2013) ${ }^{\text {Error! Bookmark not defined. }}$ However, the major issue was the concentration of immigrants in communities based on ethnic or regional backgrounds, or in mixed immigrant districts because of chain migrations (Bade, 2004). From the 1980s onward, the migration discussion was politicised and emotionalised, especially after the end of the cold war and the change in western priorities which shifted the conflicts and intensified them, particularly after the 9/11 attacks.

Indeed, during the Soviet-Afghan war (1979-1989), the 'Mujahedeen' fought the Soviet army and the allied Afghan forces, supplied with billions of dollars in arms by 'one of the longest and most expensive covert operations' of the United States Central Intelligence Agency (CIA) (Barlett \& Steele, 2003). By the end of the war, the 'Mujahedeen' became the main target of the west, especially after their official organisation, under Al-Qaeda, formed at a meeting attended by Bin Laden, Zawahiri, and Dr Fadl in Pakistan (Wander, 2008).

The politicisation of this matter took an extreme religious aspect nourished dominantly by three major factors:

- A deep feeling of discrimination and social injustice coupled with illiteracy the Muslim migrants developed due to the concentration of immigrant groups in ethnic origins.

- The failure of European foreign policies to calm the raged immigrants mainly due to considerations related to the Europe-transatlantic relations.

- A crisis of legitimacy in nearly all the Arab and Muslim worlds due to leadership failure in saving Palestine from the Zionist threat (Rogan \& Shlaim, 2007).

Therefore, in this current paper, we will reassess the EU policies in relation to these factors, readdressing their sustainable dimension as an effective answer to the insurgence of Muslim extremism within the European boundaries. This would draw a strategic roadmap to combat Muslim extremism on a sustainable basis, to substantiate the European ideals and strengthen its values. This sustainable framework will integrate social aspects with political and economic aspects, all involved in a way or another in this phenomenon.

\section{- Discrimination and Social justice}

In the background of the Muslim large-scale immigration into Europe described by De La Rica et al. (2013), there are decades of western interventions which left footprints on both Islamic world and Europe, and 
they are still affecting current socio-political and economic world panorama. Until the mid of the $20^{\text {th }}$ century, the Muslim world was colonised by Europeans who politically dominated Muslim societies in continuous struggle for independence. At the eve of the Second World War, the colonials altered the geographical map, drawing new boundaries and appointing corrupt and weak leaders over the newly carved out countries to serve western interests exclusively. Islamic fundamentalism, according to some authors, emerged in post-colonial states out of social reformist movements (Knudsen, 2003; Butterworth, 1992). However, this is seen as a reaction to the frailty and weakness of the political systems (compared to the glorious past of the Islamic nation) and the corruption that knew no limits which kept societies under poverty, illiteracy, social injustice, and human right violation and abuse. These movements longed to govern themselves by Islamic laws and rules due to the conviction that natural human freedom must be preserved by political regimes (Butterworth, 1992). Since then, the new term 'Political Islam' has been developed to define these movements which described themselves as Islamic in orientation (Mamouri, 2013; Paracha, 2014). It is important to note that 'Political Islam' is not always a synonym for violence, radicalism, and extremism (Hirschkind, 1997). For instance, in the UK, the peaceful Islamic political activity has led in 1996 to the 'Arbitration Act 1996' where 'Sharia' courts became a part of the constitutional framework (The UK Parliament, 1996).

From another side, those who left their homeland in search of different and better life conditions lived almost exclusively in urban environments, segregated in marginal districts or suburbs, and are undergoing socio-economic inequality mainly in education, housing systems, labour markets, and other opportunities undermining their social and economic wellbeing (Engstrom, 1997). Muslim immigrants who have already arrived in Europe with a deep anger and indignation for the colonials had these feelings pushed to the extremes under such conditions of social injustice. Illiteracy was the incubator, which developed these feelings into extreme behaviours.

The Palestinian problem, as described by Shlaim (2010), is 'one of the most bitter, protracted, violent and seemingly intractable conflicts of modern times'. It has existed since the British colonials have founded the state of Israel (Belfour Declaration - 1917). Ever since, the western world (including the United States) has strongly and blindly supported Israel in the continuous aggressions against Palestinians, with no distinction between civilians, women, children and elders (Holt, 2010), violating the very basics of human rights and all the international treaties, pacts, and conventions.

Indeed, since its creation in 1948, in absence of any legal and human justification, Israel (constrained by political Zionism) has been in a 
continuous military war to extract the natives from their homeland and to turn away the displaced who stayed around the borders. Furthermore, Israel declared a socio-economic and moral war against the indigenous people who did not flee their homes, to push them to do so. These policies of collective punishment have backfired and resulted in more wars locally and regionally. According to the literature, this should be classified as 'state terrorism' if we accept the definition provided in the official United States code and that of other scholars (Slater, 2015; Chomsky, 1987; Herman, 1982). A long list of documented examples might be cited here, which aim to depict the relation between discrimination and social injustice and terrorism. Along with what has been argued before, this unjust and never-ending conflict has added an amplified hatred of the Arab mass towards the western world.

\section{- Europe and Transatlantic Relations}

The idea of American hegemony is an old expression but has its practical roots in the Second World War (Beeson \& Higgott, 2005), when the United States emerged from that war as the dominant economic, political, and technological power (Heisbourg, 1999). However, according to Mearsheimer (1998), the American policy at the time was counterhegemonic to block Germany from achieving mastery over Europe and emerge as a continental hegemon, jeopardising its strategic interests (Layne, 2000).

The end of the cold war instilled American hegemony in the international system and its power especially increased in Europe, where it sought to control the European security environment to prevent the emergence of rival great powers. Since then, Washington's 'European grand strategy' has been criticised for its predominance over the development of the European 'Common Security and Defence Policy' leading to poor and harmful European strategic choices (Kempin \& Mawdsley, 2013). All wars that Europeans fought under the NATO or other western alliance in East Europe and the Middle East (Yugoslav war 1991-2001, Georgian civil wars 1991-1993, Invasion of Iraq 2003-2010 and the Syrian civil war 2011) had a direct impact on the increase of discrimination and injustice sentiments of Muslim immigrants in Europe. The latest deterioration of EU-Russian socioeconomic relations after March 2014, as a reaction to events in Crimea, is another example (Romanova, 2016). This shows how harmful some decisions could be for the member states. These policies also became subject to internal critics and serious divisions between EU members (Sedivy \& Zaborowski, 2004).

\section{- Sustainability to Combat Terrorism}

After the 9/11 attack in 2001 in the United States, the threat from terrorism became more real and evolving. Since then, billions are being spent 
globally on increased homeland security measures, which, despite the economic crisis, are increasing (Figure 2). Indeed, according to HSRC (2012), Europe spent about US $\$ 350$ billion on homeland security (45\% of the USA spending). Yet, on a global average, terrorism has claimed 67 more deaths yearly (Lomborg \& Sandler, 2008). In Europe, as mentioned previously (Section 2), security has failed to prevent painful attacks on its territory. The only cases in which attacks thwarted by authorities are the fruit of cooperation between European Intelligence services include the Bostonstyle plot to bomb cycle race near Frankfurt in Germany last May 2015 and the attempted attack with explosives at a soccer stadium in Hanover Germany in November 2015.

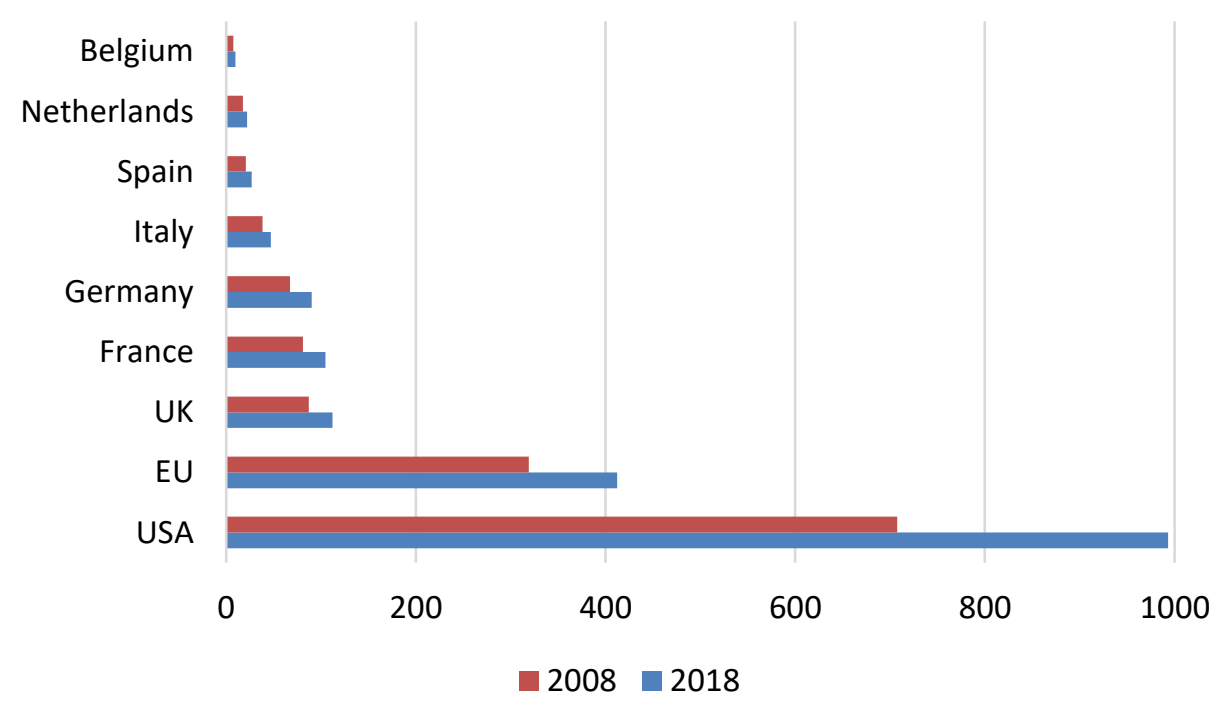

Figure 2. Spending on national security (US\$ billion) of some western countries (Modified after: HSRC, 2012).

Nevertheless, recent attacks showed that the response of the EU is still not at the level of the threats. Hence, this demonstrates that foreign EU policies are not rightly integrated into sustainability, the ethos or consensus of the Union. Even though foreign policies are directly related to social security, equity and prosperity, thus to the third sustainability dimension, the major focus of EU policies is on environment and resources (Mabey, 2007). Therefore, sustainable foreign policies based on cooperation are the key to save the EU, to fight terrorism, and to meet the 2030 Sustainable Development Goals (UN, 2015). Such policies are crucial in different areas: social justice and human rights, education, law enforcement, security and defence including intelligence sharing and military operations. 


\section{- Education}

Nelson Mandela used to say: "Education is the most powerful weapon which you can use to change the world."

Therefore, a sustainable solution of terrorism in Europe requires the identification and elimination of the root causes of fundamentalism from the post-colonial period to the post-cold war periods. It is employed to tackle the reasons for its rise in both Muslim and European countries based on a sustainable thinking and education, and not on colonial interests dictated by a rivalry for power and for resources grabbing.

This has been emphasised in mid-2016 by the Global Education First Initiative (GEFI), in a debate organised at the United Nations in New York on the prevention of violent extremism through education. This requires a systematic review of the education policies in place. This is because quality education is the passport to a sustainable future. Also, it enables future generations to constructively and creatively address present and future challenges for more resilient societies. A 'Quality Education', according to UN (2015b), should enclose all forms of learning e.g. formal, non-formal and informal, including the use of ICT because social media have a significant role to play in terrorist attacks and counterattacks.

Furthermore, education intended as a public and a global common good is a fundamental human right and a basis for guaranteeing human rights and obligations and in reaching sustainable social justice. From another side, the literature has underlined a symbiosis between media and political violence which goes back to the 1870s (Martin, 1986; Schmid, 1989); here, terrorists use the media for a variety of reasons (e.g. spreading, recruitment, indoctrination, propaganda, etc.) and the media use terrorism like any other spot in the competition for audience share (Wilkinson, 1997).

In a 'Quality Education' where the media plays a sustainable role in combatting terrorism, there is a need to review the existing journalistic codes of ethics which showed to be insufficient. Years ago, Wilkinson (1997) suggested that voluntary self-restraint and self-regulation are the best policy option for our democratic society.

\section{- Social Justice and Human Rights}

The 2030 Agenda also addresses issues such as effective institutions, good governance, the rule of law, and peaceful societies. To meet the goals of the Agenda, Europe was asked to truly and honestly work for social justice and human rights in the Middle East and find a sustainable solution for the Palestinian conflict -The evil of all evils- away from the American dictations and interests.

In Africa, social justice and human rights could be achieved through the support of good and strong leadership and governance. This is because 
bad/weak leadership have sustained poverty and illiteracy, reduced unemployment, increased corruption and social injustice, human right abuse and violation.

In fact, the 2011/2012 European Report on Development (ERD3) (2012) urged that the international community should radically transform approaches to managing water, energy, and land (WEL) - The main source of threat to the 17 Sustainable Development Goals (SDGs) -to support inclusive and sustainable growth in the poorest developing countries.

Even though the EU has significantly invested in cooperation and development programmes dealing with natural resource challenges in poor countries, these programmes have not involved direct engagement with European companies on development issues according to the ERD. Therefore, the big question is how to translate the recommendations of the report into effective actions to alleviate poverty, promote peace and justice and strong institutions, protect equality and save the overall sustainability, mainly posed by resources grabbing (Dell'Angelo et al., 2017).

\section{- Law Enforcement}

Despite widespread awareness and acceptance of the necessity for developing a comprehensive response to terrorism in international criminal law, attempts to realise this objective have been beset by more controversy, due to the absence of a clear and unique definition (Stephens, 2004). The international counter-terrorism law therefore remains a major limitation for law enforcement, without which expressions such as 'war on terror' and 'war on terrorism' can be empty expressions content employed for political struggles and conflicts and private interests (Herman \& Peterson, 2005), e.g. international human rights NGOs have been warning that human rights have been seriously threatened since the September 11 attacks (Dunér, 2005), in the most democratic countries in both USA (Kaplan, 2006) and the EU member states (Gregory, 2005).

Once again, the EU needs to allocate further efforts and work with the international community to define 'terrorism' and reinforce international criminal law for a sustainable social justice. The EU is also called to publicly repudiate all forms of injustice and the infringement of international laws, and to exert additional diplomatic efforts on USA to stop such practices (Amnesty International, 2008).

Furthermore, the post-9/11 period has known a structural change at the level of EU member states in terms of counterterrorism politics. Yet, there are limits to developing robust counterterrorism capacities on the supranational level. Under its current structure, the Union (EU legislative assembly and the European parliament) does not have a mandate to 
implement and enforce the decisions, which are only political and thus nonbinding (Zimmermann, 2006).

Legislative reforms should take place to give enforcement power to the Union for the implementation of counterterrorism measures, as terrorism became a Union concern rather than an internal security issue.

\section{- A Sustainable Common Defence Policy}

The integration of the previous policies and measures with a sustainable security and defence strategy is very important to combat terrorism because it gives the capacity for immediate responsiveness.

The lack of effective and efficient intelligence and military cooperation, in a common defence policy, has been the subject of many studies (Birsan, 2012). The European Union Common Foreign Security Policy (CFSP) addressed this issue as a response to the increased threats. The policy commits its member states to strengthen the EU's external ability to act militarily and influence policies violating international law or human rights, or policies disrespectful of the rule of law or democratic principles.

More recently, in its council conclusions, the EU Foreign Council Affairs has determined the most important strategic priorities for implementing the EU Global Strategy (EU-FCA, 2016). These are Security and Defence, Building Resilience and taking an Integrated Approach to conflicts and crises, addressing the Internal/External Nexus, updating existing strategies and preparing new ones, and enhancing Public Diplomacy.

However, this requires continuous evaluation and updating, to increase the effectiveness and efficiency of the EU CFSP, consolidating democracy and improving civil-military relations at the union level, for a sustainable development. There are major trade-offs to face in this regard, which make the situation complex to manage sustainably (Bruneau \& Matei, 2008).

\section{Conclusion}

It is true that 1957 marked the beginning of cooperation between different European countries known at that time as the European Economic Community (EEC) created with the Treaty of Rome. This cooperation came out of a strategic need after the end of the Second World War dominated by the cold war between east and west. However, the introduction of sustainability as a philosophy, inspiring all the Union's policies and decisions, has become the consensus of the Union. This so-called ethos, basic in defining any society and uniting its members (Bar-Tal, 2002), has been fundamental in the development of the European identity, and in conferring a sense of belonging and identification. 
The EU foreign policies from the post-war until today have been from one side an expression of USA's wishes to guarantee its interests worldwide. This is regardless of the harm on the EU member states, e.g. the war in Donbass (Ukraine), the Iraq war, the Syrian civil war, the Saudi-led multinational coalition in Yemen, etc. From another side, it is a continuation of hegemonic imperialist interests with the developing countries and the excolonials, e.g. land, water and resources grabbing. In both ways, these policies have been totally unsustainable: they have generated social and environmental devastations around the world, they have amplified the hatred for many EU member states, and they have become a continuous threat to the EU national security. Continuing with the same unsustainable policies may mark the end of the union. The simple reason that these policies have distorted the basic ethos of the union is enough reason to put an end to the union. The Brexit referendum in June 2016 was an obvious first consequence, followed by the Catalan independence referendum in October 2017. These socio-political events might not stop at this point, but might have the effect of the domino theory.

Therefore, to save the Union from falling apart and to fight terrorism are two complementary issues that go side by side. The framework suggested in this paper is based on sustainable education, social justice and human rights, law enforcement and a sustainable common defence policy; it is a road map towards a sustainable solution. However, this can only be applied after addressing the EU-transatlantic relations and dissociate the European decision from the American hegemonic dictations and interests.

\section{References:}

1. Alex Conte (2010). "The nature and definition of terrorism", in Human rights in the prevention and punishment of terrorism, Springer Berlin Heidelberg, pp 7-37, http://dx.doi.org/10.1007/978-3642-11608-7_2.

2. Alex P Schmid (1989). "Terrorism and the media: The ethics of publicity", Terrorism and Political Violence, 1:4, pp 539-565, http://dx.doi.org/10.1080/09546558908427042.

3. Ali Mamouri (2013). "The roots of radicalism in Political Islam", $A l$ Monitor: The pulse of the Middle East, http://www.almonitor.com/pulse/originals/2013/10/radicalism-political-islamroots-sunnishiite-fundamentalist.html.

4. Amnesty International (2008). "Impunity and injustice in the "war on terror' - From torture in secret detention to execution after unfair trial?", AMR 51/012/2008, https://www.amnesty.ie/wpcontent/uploads/2016/04/Impuntiy-andInjustice-in-the-War-on-Terror.pdf. 
5. Andrew Wander (2008). "A history of terror: Al-Qaeda 1988-2008", The Guardian, July, http://www.theguardian.com/world/2008/jul/13/history.alqaida.

6. Are J Knudsen (2003). "Political Islam in the Middle East", CMI Reports, Chr. Michelsen Institute, $31 \mathrm{p}$.

7. Avi Shlaim (2010). Israel and Palestine: reappraisals, revisions, refutations, Verso, $392 \mathrm{p}$.

8. Bjørn Lomborg \& Todd Sandler (2008). "Re-Thinking CounterTerrorism”. Project Syndicate, Copenhagen Consensus Center.

9. Bertil Dunér (2005). "Disregard for security: The human rights movement and 9/11", Terrorism and Political Violence, 17:1-2, pp 89-104, http://dx.doi.org/10.1080/09546550590520609.

10. Bruce Hoffman (2006). "Inside terrorism", Colombia University Press, $456 \mathrm{p}$.

11. Charles E Butterworth (1992). "Political Islam: the origins". The Annals of the American Academy of Political and Social Science, 524, pp 26-37.

12. Charles Hirschkind (1997). "What is Political Islam", Middle East Research and Information Project (MER205), http://www.merip.org/mer/mer205/what-political-islam.

13. Charles Malik (2015). "Christ and crisis - Orthodox Christian social thought", Acton Institute, $111 \mathrm{p}$.

14. Christopher Layne (2000). "US hegemony and the perpetuation of NATO”, Journal of Strategic Studies, 23 (3), pp 59-91, http://dx.doi.org/10.1080/01402390008437800.

15. Constantin-Marian Birsan (2012). "Intelligence effectiveness in the European Union (EU) in the new security environment", (MA Thesis from the Naval Postgraduate School, Monterey, California (USA), 89 p.

16. Daniel Bar-Tal (2002). Shared beliefs in a society: social psychological analysis, SAGE Publications, Inc., 232 p.

17. David M Engstrom (1997). "The economic determinants of ethnic segregation in Post-War Britain", Discussion Papers in Economic and Social History (12), 44 p, www.nuff.ox.ac.uk/economics/history/paper12/12paper.pdf.

18. Donald, L Barlett \& James B Steele (2003). "The oily Americans", Time Magazine, May 13, http://content.time.com/time/magazine/article/0,9171,450997,00.html

19. Doron Zimmermann (2006). "The European Union and Post-9/11 counterterrorism: A reappraisal", Studies in Conflict \& Terrorism, 29 (2), pp 123-145, https://doi.org/10.1080/10576100500522215 
20. Edward S Herman (1982). The real terror network: Terrorism in fact and propaganda, South End Press, $252 \mathrm{p}$.

21. Edward S Herman \& David Peterson (2008). "There is no war on terror", ColdType, http://coldtype.net.

22. Eugene L Rogan \& Avi Shlaim (2007). The war for Palestine: Rewriting the History of 1948, Cambridge University Press, 285 p.

23. EU-FCA (2016). "Council conclusions on the global strategy on the European Union's foreign and security policy", The European Union Foreign Council Affairs (FCA), http://www.consilium.europa.eu/en/press/press-releases/2016/10/17fac-eu-global-strategy/.

24. Francois Heisbourg (1999). "American hegemony? Perceptions of the US abroad”, Survival, 41 (4) (1999), pp 5-19, http://dx.doi.org/10.1080/713660132.

25. Frank Gregory (2005). “The EU's response to 9/11: A case study of institutional roles and policy processes with special reference to issues of accountability and human rights", Terrorism and Political Violence, $17: 1-2, \quad$ pp 105-123, http://dx.doi.org/10.1080/09546550590520618.

26. Garikai Chengu (2014). "America Created Al-Qaeda and the ISIS Terror Group". Global Research, http://www.globalresearch.ca/.

27. HSRC (2012). "Global homeland security \& public safety market 2015-2022”, Homeland Security Research Corporation (HSRC), $1559 \mathrm{p}$.

28. Leonard Weinberg, Ami Pedahzur \& Sivan Hirsch-Hoefler (2004). "The challenges of conceptualizing terrorism", Terrorism and Political Violence, $16 \quad$ (4), pp 777-94, http://dx.doi.org/10.1080/095465590899768.

29. Jampel Dell'Angelo, Paolo D’Odorico \& Maria Cristina Rulli (2017). "Threats to sustainable development posed by land and water grabbing”, Current Opinion in Environmental Sustainability, 26-27, pp 120-128, https://doi.org/10.1016/j.cosust.2017.07.007.

30. Jeffrey Kaplan (2006). "Islamophobia in America?: September 11 and Islamphobic hate crime", Terrorism and Political Violence, 18:1 (2006), pp 1-33, http://dx.doi.org/10.1080/09546550500383209.

31. Jeffrey D Simon (1994). "The terrorist trap: America's experience with terrorism", Indiana University Press, $484 \mathrm{p}$.

32. Jerome Slater (2015). "Terrorism and the Israeli-Palestinian conflict: An argument" Middle East Policy, XXII (3), pp 79-99, http://dx.doi.org/10.1111/mepo.12145. 
33. Jiri Sedivy \& Marcin Zaborowski. "Old Europe, New Europe and Transatlantic Relations", European Security, 13 (3), pp 187-213, http://dx.doi.org/10.1080/09662830490499948.

34. John J Mearsheimer (1998). "The future of America's continental commitment", in: No End to Alliance: The United States and Western Europe: Past, Present and Future, ed. Geir Lundestad (Palgrave Macmillan, 1998), pp 221-44, https://doi.org/10.1007/978-1-34926959-4_11.

35. John L Martin (1986). "The media's role in international terrorism", Terrorism, $8: 2$, $\mathrm{pp}$ http://dx.doi.org/10.1080/10576108508435597.

127-146,

36. Jonathan Matusitz (2013). "Terrorism and Communication: A Critical Introduction", SAGE Publications, Inc., $520 \mathrm{p}$.

37. Klaus J Bade (2004). "Legal and illegal immigration into Europe: experiences and challenges", European Review, 12 (3), pp 339-75, http://dx.doi.org/10.1017/S1062798704000316.

38. Maria Holt (2010). "Palestinian women, violence, and the peace process" Development in Practice, 13 (2-3), 223-238, http://dx.doi.org/10.1080/09614520302948.

39. Mark Beeson \& Richard Higgott (2005). "Hegemony, institutionalism and US foreign policy: theory and practice in comparative historical perspective" Third World Quarterly, 26 (7), pp 1173-88, http://dx.doi.org/10.1080/01436590500235777.

40. Martin Miller (2012). "The foundations of modern terrorism: State, society and the dynamics of political violence", Cambridge University Press, 292 p.

41. Nadeem F Paracha (2014). "Political Islam: An evolutionary history", Dawn, https://www.dawn.com/news/1139847.

42. Noam Chomsky (1987). "International terrorism: Image and reality", Crime and Social Justice, 27/28, pp 172-200, http://www.jstor.org/stable/29766332.

43. Nick Mabey (2007). "Sustainability and foreign policy", in: Progressive foreign policy: new directions for the UK, ed. David Held and David Mepham, (Polity), pp 99-115.

44. OPSEC (1996). "Operations Security: Intelligence threat handbook", The Interagency

OPSEC, http://fas.org/irp/nsa/ioss/threat96/index.html.

45. Paul Wilkinson (1997). "The media and terrorism: A reassessment", Terrorism and Political Violence, 9:2, pp 51-64, http://dx.doi.org/10.1080/09546559708427402.

46. Piero Giorgi (2001). "The origins of violence by cultural evolution", Minerva E \& S, , 214 p. 
47. PRC (2011). "The future of the global Muslim population. Projections for 2010-2030”, Pew Research Center (PRC), Forum on Religion \& Public Life, $209 \quad$ p, file://C:/Users/User1/Downloads/FutureGlobalMuslimPopulationWebPDF-Feb10.pdf.

48. Rhonda Callaway \& Julie Harrelson-Stephens (2006). "Toward a Theory of Terrorism: Human Security as a Determinant of Terrorism", Studies in Conflict \& Terrorism, 29 (7), pp 679-702, http://dx.doi.org/10.1080/10576100600701974.

49. Robert Leiken (2005). "Europe's angry Muslims", Foreign Affairs, July/August, https://www.foreignaffairs.com/articles/europe/200507-01/europes-angry-muslims.

50. Ronja Kempin \& Jocelyn Mawdsley (2013). "The common security and defence policy as an act of American hegemony", European $\begin{array}{llll}\text { Security, } & 22 & \text { (1), } & \text { pp }\end{array}$ http://dx.doi.org/10.1080/09662839.2012.726221.

51. Sara de la Rica, Albrecht Glitz \& Francisco Ortega (2013). "Immigration in Europe: Trends, Policies and Empirical Evidence" The Institute for the Study of Labour (IZA), Discussion Paper (No. 7778), http://ftp.iza.org/dp7778.pdf.

52. Tatiana Romanova (2016). "Sanctions and the Future of EU-Russian Economic Relations”, Europe-Asia Studies, 68 (4), pp 774-96, http://dx.doi.org/10.1080/09668136.2016.1159664.

53. Tim Stephens (2004). "International Criminal Law and the Response to International Terrorism", UNSW Law Journal, 27 (2), pp 454-481.

54. The 2011/2012 European Report on Development, "Confronting Scarcity: Managing Water, Energy and Land for Inclusive and Sustainable Growth", Overseas Development Institute (ODI), European Centre for Development Policy Management (ECDPM), German Development Institute/Deutsches Institut für Entwicklungspolitik (GDI/DIE), 186 p.

55. The UK Parliament, "Arbitration Act 1996 - Chapter 23", Legislation.gov.uk, https://www.legislation.gov.uk/ukpga/1996/23/contents.

56. Thomas C Bruneau \& Florina Cristiana Matei (2008). "Towards a New Conceptualization of Democratization and Civil-Military Relations", Democratization, 15 (5), pp 909-29, http://dx.doi.org/10.1080/13510340802362505.

57. UN (2015). "International Migration Flows to and from Selected Countries: The 2015 Revision”, POP/DB/MIG/Flow/Rev.2015, Department of Economic and Social Affairs, Population Division ed., United Nations (UN), (2015a), 11 p, 
http://www.un.org/en/development/desa/population/migration/data/e mpirical2/migrationflows.shtml.

58. UN (2015). "Transforming our world: The 2030 Agenda for Sustainable Development", A/RES/70/1, The United Nations (UN), (2015b), 35

$\mathrm{p}$, http://www.un.org/ga/search/view_doc.asp?symbol=A/RES/70/1\&La $\mathrm{ng}=\mathrm{E}$. 